Nat. Hazards Earth Syst. Sci., 18, 1349-1350, 2018

https://doi.org/10.5194/nhess-18-1349-2018

(C) Author(s) 2018. This work is distributed under

the Creative Commons Attribution 4.0 License.

\title{
Preface: Linking faults to seismic hazard assessment in Europe
}

\author{
Bruno Pace ${ }^{1}$, Francesco Visini ${ }^{2}$, Oona Scotti ${ }^{3}$, and Laura Peruzza ${ }^{4}$ \\ ${ }^{1}$ DiSPUTer, Università “G. d'Annunzio" Chieti-Pescara, Chieti, Italy \\ ${ }^{2}$ Istituto Nazionale di Geofisica e Vulcanologia, L'Aquila, Italy \\ ${ }^{3}$ Bureau d'Evaluation des Risques Sismiques pour la Sûreté des Installations, \\ Fontenay-aux-Roses, 92262, France \\ ${ }^{4}$ Istituto Nazionale di Oceanografia e di Geofisica Sperimentale - OGS, Sgonico (TS), Italy \\ Correspondence: Bruno Pace (bruno.pace@ unich.it)
}

Published: 15 May 2018

The title of this special issue, "Linking faults to seismic hazard assessment in Europe", is the result of a challenging experiment that we have been carrying out for a few years: creating a working group of field geologists, fault modellers, data modellers, and seismic hazard practitioners to discuss and share ideas, promote initiatives to strengthen collaborations, and improve knowledge and practice of fault-based seismic hazard assessment. This special issue was designed in the framework of activity of the Fault2SHA Working Group (formally approved by the European Seismological Commission - ESC - at the 35th General Assembly, held in Trieste (Italy), in September 2016, http://www.fault2sha.net, last access: 9 May 2018).

The key questions the Fault2SHA Working Group asked the research community with this special issue were as follows. What is the best strategy to fill in the gap in knowledge and expertise in Europe when considering faults in seismic hazard assessments? Are field geologists providing the relevant information for seismic hazard assessment? Are seismic hazard analysts interpreting field data appropriately? Is the full range of uncertainties associated with the characterization of faults correctly understood and propagated in computations? How can fault modellers contribute to a better representation of the long-term behaviour of fault networks in seismic hazard studies?

Providing answers to these questions is fundamental in order to reduce the consequences of future earthquakes and improve the reliability of seismic hazard assessments.

This special issue includes 11 papers focused on data gathering (García-Mayordomo et al., 2017; Hintersberger et al., 2018; Jomard et al., 2017) as well as seismic and surface rupture hazard modelling (Avital et al., 2018; Valentini et al.,
2017; Chartier et al., 2017a, b; Gülerce et al., 2017; Azzaro et al., 2017; Peruzza et al., 2017; Boncio et al., 2018).

Key points of the papers are as follows:

1. García-Mayordomo et al. (2017) discuss the process of updating and reviewing the Quaternary Active Fault Database of Iberia (QAFI); the authors devoted particular attention to describing the scheme devised for classifying the quality and representativeness of the geological evidence of Quaternary activity and the accuracy of slip rate estimation.

2. Hintersberger et al. (2018) show palaeoseismological investigations at an active fault of the Vienna Basin (Austria); this case study provided a good example of the necessity of combining more than one field observation and estimating the related uncertainties.

3. Jomard et al. (2017) and Chartier et al. (2017a) are two companion papers devoted to the development of an active fault database for metropolitan France (Part 1) and its transposition into a fault model for probabilistic seismic hazard analysis in the Upper Rhine Graben (Part 2).

4. Avital et al. (2018) discuss the effect of alternative seismotectonic models on seismic hazard analysis for two sites in Israel, one in the near-fields of a major fault system and one farther away.

5. Valentini et al. (2017) propose a new probabilistic seismic hazard model for Italy that integrates active faults and seismological data in seismic hazard estimations. 
6. Gülerce et al. (2017) provide a seismic source characterization model used in the probabilistic seismic hazard assessment for Istanbul (Turkey).

7. Azzaro et al. (2017) and Peruzza et al. (2017) are two companion papers concerning the seismic hazard assessment of Mt Etna (Italy); the first paper tackles the problem of characterizing low-magnitude and shallow seismic sources in a volcanic area, while the second one presents specific implementations and first seismic hazard results obtained for Mt Etna.

8. Chartier et al. (2017b) present a novel methodology that uses a system-level approach rather than an individualfault-level approach to estimate the rate of earthquakes on faults; the methodology was tested on the western Corinth Rift (Greece).

9. Boncio et al. (2018) discuss surface rupture hazard issues related to the collection of data from well-studied surface faulting thrust/reverse earthquakes around the world, the statistical analysis of the distribution of surface ruptures, and the implications for earthquake fault rupture zoning.

The aim of this special issue, in the framework of the Fault2SHA activities, was to motivate scientific exchanges among contributors from different disciplines, promoting growth of the community with a common language aimed to understand how faults can best be incorporated in seismic hazard studies; we believe that the papers in this volume pose a first step towards achieving this goal.

Acknowledgements. We gratefully acknowledge the chief editor, Stefano Tinti, the editorial staff and the authors for giving us the opportunity to publish this special issue. Finally, we, as guest editors, would like to express our gratitude to Stéphane Baize, Celine Beauval, Dan Clark, Edward Marc Cushing, Laurentiu Danciu, Julian Garcia-Mayordomo, Ryan Gold, Nicola Litchfield, Franz Livio, Kuo-Fong Ma, Maria Ortuno, Kris Vanneste, Graeme Weatherill and the anonymous referees for their constructive reviews.

\section{References}

Avital, M., Kamai, R., Davis, M., and Dor, O.: The effect of alternative seismotectonic models on PSHA results - a sensitivity study for two sites in Israel, Nat. Hazards Earth Syst. Sci., 18, 499-514, https://doi.org/10.5194/nhess-18-499-2018, 2018.

Azzaro, R., Barberi, G., D’Amico, S., Pace, B., Peruzza, L., and Tuvè, T.: When probabilistic seismic hazard climbs volcanoes: the Mt. Etna case, Italy - Part 1: Model components for sources parameterization, Nat. Hazards Earth Syst. Sci., 17, 1981-1998, https://doi.org/10.5194/nhess-17-1981-2017, 2017.
Boncio, P., Liberi, F., Caldarella, M., and Nurminen, F.-C.: Width of surface rupture zone for thrust earthquakes: implications for earthquake fault zoning, Nat. Hazards Earth Syst. Sci., 18, 241 256, https://doi.org/10.5194/nhess-18-241-2018, 2018.

Chartier, T., Scotti, O., Clément, C., Jomard, H., and Baize, S.: Transposing an active fault database into a fault-based seismic hazard assessment for nuclear facilities - Part 2: Impact of fault parameter uncertainties on a site-specific PSHA exercise in the Upper Rhine Graben, eastern France, Nat. Hazards Earth Syst. Sci., 17, 1585-1593, https://doi.org/10.5194/nhess17-1585-2017, 2017a.

Chartier, T., Scotti, O., Lyon-Caen, H., and Boiselet, A.: Methodology for earthquake rupture rate estimates of fault networks: example for the western Corinth rift, Greece, Nat. Hazards Earth Syst. Sci., 17, 1857-1869, https://doi.org/10.5194/nhess17-1857-2017, 2017b.

García-Mayordomo, J., Martín-Banda, R., Insua-Arévalo, J. M., Álvarez-Gómez, J. A., Martínez-Díaz, J. J., and Cabral, J.: Active fault databases: building a bridge between earthquake geologists and seismic hazard practitioners, the case of the QAFI v.3 database, Nat. Hazards Earth Syst. Sci., 17, 1447-1459, https://doi.org/10.5194/nhess-17-1447-2017, 2017.

Gülerce, Z., Bugra Soyman, K., Güner, B., and Kaymakci, N.: Planar seismic source characterization models developed for probabilistic seismic hazard assessment of Istanbul, Nat. Hazards Earth Syst. Sci., 17, 2365-2381, https://doi.org/10.5194/nhess17-2365-2017, 2017.

Hintersberger, E., Decker, K., Lomax, J., and Lüthgens, C.: Implications from palaeoseismological investigations at the Markgrafneusiedl Fault (Vienna Basin, Austria) for seismic hazard assessment, Nat. Hazards Earth Syst. Sci., 18, 531-553, https://doi.org/10.5194/nhess-18-531-2018, 2018.

Jomard, H., Cushing, E. M., Palumbo, L., Baize, S., David, C., and Chartier, T.: Transposing an active fault database into a seismic hazard fault model for nuclear facilities - Part 1: Building a database of potentially active faults (BDFA) for metropolitan France, Nat. Hazards Earth Syst. Sci., 17, 1573-1584, https://doi.org/10.5194/nhess-17-1573-2017, 2017.

Peruzza, L., Azzaro, R., Gee, R., D’Amico, S., Langer, H., Lombardo, G., Pace, B., Pagani, M., Panzera, F., Ordaz, M., Suarez, M. L., and Tusa, G.: When probabilistic seismic hazard climbs volcanoes: the Mt. Etna case, Italy - Part 2: Computational implementation and first results, Nat. Hazards Earth Syst. Sci., 17, 1999-2015, https://doi.org/10.5194/nhess-17-1999-2017, 2017.

Valentini, A., Visini, F., and Pace, B.: Integrating faults and past earthquakes into a probabilistic seismic hazard model for peninsular Italy, Nat. Hazards Earth Syst. Sci., 17, 2017-2039, https://doi.org/10.5194/nhess-17-2017-2017, 2017. 